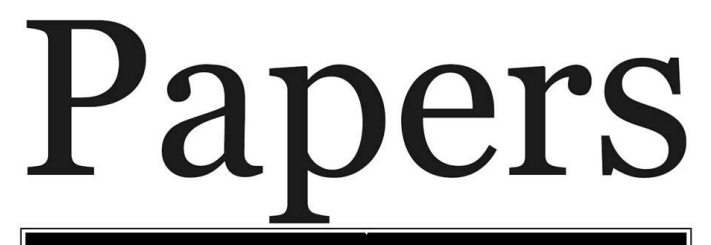

Explorations into Children's Literature

\title{
Daughters of The Handmaid's Tale: Reproductive Rights in YA Dystopian Fiction
}

\author{
Dr. Ilona Urquhart - Deakin University
}

\begin{abstract}
The election of President Trump in the US has reignited discussions regarding reproductive rights and renewed interest in Margaret Atwood's 1984 dystopian novel, The Handmaid's Tale, which depicts a future society in which women are stripped of these rights. However, the novel does not explore how threats to reproductive rights might affect teenage girls. The gap left in Atwood's novel has been filled by authors of dystopias for young adults who foreground the double threat to teenage girls because of their sex and age. This paper discusses the way in which these novels show teenage girls resisting against societies that seek to dictate how they use their bodies, with Megan McCafferty's Bumped and Thumped having a particularly strong political edge. Through the insights of feminist critic Drucilla Cornell, this paper shows that the challenges to characters' reproductive rights in these texts may encourage readers to consider themselves as sexual subjects and take responsibility for that sexual subject, even if it requires political action.
\end{abstract}

Keywords: Reproductive rights, Young adult fiction, Dystopias in fiction, Adolescent sexuality in fiction, feminism

Margaret Atwood's 1985 dystopian novel The Handmaid's Tale was already being adapted as a mini-series when Donald Trump won the presidential election and threatened the already precarious state of reproductive rights in the United States, making it 'accidentally the most prescient story on TV', in the words of its star Elisabeth Moss (cited in Dockterman, 2017, p.

2). The novel depicts a society called the Republic of Gilead, that has withdrawn women's rights in order to force the few who remain fertile to bear children for the wealthy.

Following the election, Atwood herself warned that ' $[w] e^{\prime}$ re heading into a situation in which health coverage is going to be removed from pregnancy and childbirth. At the same time, 
you're going to force women to have babies by making it so they can't get abortions... If you're going to take away women's choice and not give them an adequate wage or healthcare, what would you call that?' (cited in Dockterman, 2017, p. 2). Although a work of fiction, all the restrictions and practices depicted in the dystopian future of The Handmaid's Tale have historical or modern-day precedent (Mead, 2017, p. 40). As the director of the 'Twentieth and Twenty-First Century Archives' at Cambridge University remarks in the fictional concluding historical notes to the novel, 'there was little that was truly original with or indigenous to Gilead: its genius was synthesis' (Atwood, 1985, p. 319). As such, the novel functions as a powerful reminder of the link between women's autonomy, power and reproductive rights. ${ }^{i}$

The ongoing relevance of Atwood's literary creation has led her to announce recently that the sequel The Handmaid's Tale, The Testaments, will be published in September 2019 (Penguin Books, 2018). In the meantime, the novel continues to experience a resurgence in popularity with a return to bestseller lists, including American retailer Barnes \& Noble's Teen Bestsellers (Teen Bestsellers, 2017). It was also the May/June selection for Emma Watson's 195,115 member 'Feminist book club' Our Shared Shelf on the website Goodreads (2017). Although Watson is now in her late twenties and a United Nations Women Goodwill Ambassador, her fame as Hermione Granger in the Harry Potter series of films means that her adolescent fans are likely to become exposed to Atwood's novel and the discussions regarding reproductive rights that it has sparked since its original publication.

However, The Handmaid's Tale is largely concerned with the experiences of adult characters, with the narrative focalised through Offred, a woman of thirty-three (Atwood, 1985, p. 153). Offred's age allows her to contrast her life as a Handmaid in the totalitarian Republic of Gilead with her former life, when she was university educated and lived with a divorced man and their daughter. The passionate relationship Offred once shared with Luke is presented in stark contrast to the clinical mandated sexual ritual or 'Ceremony' that she must regularly perform with her Commander and his wife, justified by the biblical narrative of Rachel and her handmaiden Bilhah, who was given to Rachel's husband to bear children. When Offred 
observes the only teenaged characters depicted in the novel-young girls called 'Angels' participating in a group ceremony of arranged marriages-she remarks that they would remember 'the time before, playing baseball, in jeans and sneakers, riding their bicycles' but it would only be a few years before the girls being married will 'have always been in white, in groups of girls; they'll always have been silent' (p. 231), knowing no other life. This implies that teenagers do not play any significant role in the novel because the teenage girls of Gilead only know what it is like to be a child and to be Angels-sexuality is ostensibly only part of the adult world. In reality, though, this cannot possibly be the case: '[a]lthough many parents, teachers, politicians, and adolescents themselves might prefer that sexuality were not involved in the process of moving from childhood to adulthood, it is' (Tolman, Striepe, \& Harmon, 2003, p. 4).

Given The Handmaid's Tale's mid-eighties publication, the omission of teenagers and teenage concerns from the novel may be related to the state of feminism at the time. In her discussion of teenage feminists, Kera Lovell comments that, despite the presence of secondwave teenage feminists who 'argued that the sexualization of and discrimination against girls trained them for subservience' $(2016$, p. 72$)$, the movement was predominantly 'adultdominated' compared to the 'girl-focused Third wave' (p. 71). Consequently, the early twenty-first century has seen the publication of dystopian novels that can be considered daughters of The Handmaid's Tale in that, even though there is no intertextual link between them, they address the same issue of reproductive rights from the perspective of adolescent girls. Texts such as Megan McCafferty's Bumped (2011) and Thumped (2012), Lauren Destefano's Wither (2011), the first in the Chemical Garden trilogy, and Jane Rogers' The Testament of Jessie Lamb (2011) depict worlds in which teenage girls are the only group capable of bearing children in worlds facing dramatic population losses. The purpose of this paper, consequently, is to elucidate how these twenty-first century dystopian young adult (YA) novels expand on Atwood's exploration of the fragility of reproductive rights by showing how teenage girls' bodily autonomy and reproductive rights are doubly at risk because of their sex and age, with Thumped directly calling for teenage girls to be aware and take action to defend their rights. These issues will be considered primarily in light of the 
work of feminist scholar Drucilla Cornell, whose concept of the 'imaginary domain' will be applied to moments of self-discovery depicted in the texts, to explore their representations of feminine and feminist identity formation.

Cornell writes passionately about the 'right to the imaginary domain,' understood as '[t]he freedom to create ourselves as sexed beings, as feeling and reasoning persons... to be ourselves and [enjoy] participation in the richness of life' (Cornell, 1998, p. ix). She considers it to be a 'psychic and moral space' in which we can 'evaluate and represent who we are' (1998, p. x). The biological disparity in procreation has historically been used to enable men alone to be free citizens (Cornell, 1998). Conversely, women's sexualities and identities are often assumed to be shaped by or subordinate to their reproductive capacities (Cornell, $1995,1998)$, making the right to the imaginary domain particularly important for women, in Cornell's view. If they do not have this right, women can be denied personhood because of the way they use their bodies-'exclu[ded] from the moral community of persons' and 'rendered socially dead' (Cornell, 1998, p. 21). This concept elucidates the social controls underpinning the dystopian worlds of the texts discussed in this paper. However, reading dystopian YA fiction in light of Cornell is effectively seeking the light of utopia in dystopia. As Cornell contends, 'Utopianism has always been tied to the imagination, to visions of what is truly new. A world in which we could all share in life's glories [through the imaginary domain] would be one radically different from our own society' (Cornell, 1998, p. 186). Thus, texts that can be read in light of the imaginary domain offer a glimmer of hope that suggests that the depicted dystopian world is not an inevitability.

In addition to depicting protagonists who undergo a process of self-discovery, the discussed texts thematise the issue of reproductive rights-a necessary precursor to the imaginary domain. For Carole H. Browner, 'reproductive rights' refers to the ability of individuals, but generally women, to 'act in their own reproductive interests' (2015, p. 2) and maintain bodily integrity or autonomy and sexual self-determination. Reproductive rights are largely determined by socio-political conditions, particularly as the concept of 'rights' is a Western concept in which rights are given by those in authority and may be fought for and claimed by 
those who do not have them (Browner, 2015, pp. 2-3). Although the rubric of reproductive rights also includes sex education, freedom from rape and forced marriage, contraception, access to medical care, and privacy and autonomy in regards to these matters, abortion is the most contentious example of reproductive rights. As previously suggested, Cornell's position on bodily autonomy means that she cannot avoid the abortion debate; indeed, she states unequivocally that 'the right to abortion must be guaranteed, as it is absolutely essential to the establishment of the minimum conditions for individuation' $(1995$, p. 21). This principle underlies the feminist pro-choice position through which this paper will analyse dystopian YA texts.

For instance, in her polemical Pro: Reclaiming Abortion Rights, Katha Pollitt also argues that laws legalising abortion, such as America's Roe $v$. Wade, are essential to women's bodily autonomy in that they enable women to become 'mothers by choice, not fate,' with the absence of such laws rendering

all pregnant women less than full citizens, including those who want to have a baby, because it places the supposed interests of the fetus ahead of the woman's own interests and deprives her of rights grants to everyone else: to make one's own medical decisions and to receive equal treatment under the law. (2015, pp. 3, 127)

Lynne Newhall's (2011) analysis of the United Kingdom's Abortion Act 1967 (still valid in all parts of the United Kingdom except Northern Ireland), can be applied to most-if not allplaces where abortion can be accessed legally. Although Newhall approves of the Act's recognition of abortion as a medical procedure rather than a criminal matter, she warns that it in addition to recognising the doctor's professional expertise, it also gives the doctor moral authority over the decision to grant an abortion-'at no time is a woman legally entitled to authorise the termination of her pregnancy herself' (2011, p. 65). Pollitt argues that the antiabortion belief that a fertilised egg has the right to make use of a woman's body has a precedent in the historical view of the woman's body as the property of 'her nation, her 
community, her father, her family, her husband' (2015, p. 4), implying that the pro-choice acceptance of the medical professional's role in the process also derives from the same precedent. While the Act ostensibly upholds the woman's right to bodily autonomy over the fertilised egg or foetus' right to life, the requirement that the decision be granted by a doctor (or in the case of Abortion Act 1967, two) whose moral values may not align with the patient's is problematic. Regardless of whether doctors are able to make conscientious objections to abortion or referral to abortion providers, this 'makes the state [and the medical profession] as important a determinant of the meaning of pregnancy as the woman herself,' 'an inherent devaluation of women's own capacity for moral judgement' (Cornell, 1995, p. 26).

For teenagers, though, this infringement on their bodily autonomy and undermining of their moral judgement is exacerbated by further constraints related to their age and legal dependency on their parents. In the majority of American states, for instance, parental notification or consent is required for a minor to obtain an abortion (Solinger, 2007). The external controls on adolescents' reproductive freedom can be associated with laws dictating the age at which they can consent to sexual activity. Joseph J. Fischel argues that '[f]rom childhood to adolescence to adulthood, the guiding metric of sexual consent ought to gradually shift focus from capacity to voluntariness', but the reality is often arbitrary, as 'some age of consent laws suppose an uncomplicated division between incapable children and volitional adults (a switch)' (2016, pp. 102, 103). Age, then, is often used as a proxy for the moral qualities that tend to coincide with youth-naivety, inexperience, rashness, and ignorance-rather than genuinely reflecting an individual's personal capacity (Anderson \& Claassen, 2012, p. 501). Until they reach an age at which they are considered a legal adult, then, teenagers are often subject to external controls and judgements related entirely to their age.

To a significant degree, the idea that teenagers require legal and parental supervision and guidance in relation to their reproductive rights, and the questioning of the appropriateness of teenagers' expressions of sexuality, is the heritage of the Romantic understanding of 
childhood as a period of innocence (Kokkola, 2013). In addition, as Roberta S. Trites demonstrates in her seminal work Disturbing the Universe: Power and Repression in Adolescent Literature (1998, p. 85), adults' need to regulate teenagers' sexuality shows that sexuality is a known locus of power. Lydia Kokkola expands on Trites' insight with her statement that '[s]ince sexual activity is deemed adult, teenagers who are sexually active are perceived as demanding adult power for themselves' (2013, p. 8). In the dystopian worlds whose survival depends on teenagers engaging in sexual activity, then, the adults who seek to retain their power must ensure that they retain control over teenagers' sexual activity. Thus, the plots and themes of the aforementioned 'daughters of The Handmaid's Tale' are a potentially effective way to draw young readers' attention to the ways that their sexual autonomy is constrained by their age, and for female adolescent readers, doubly by their gender.

Although the Romantic concept of the child informs the restrictions placed on the child and adolescent by the law and their parents, it also characterises young people as the hope for the future which, Elizabeth Bullen and Elizabeth Parsons write, 'militates against the dystopic impulse in ways that typically refigure the genre in its children's literature manifestation' (2007, pp. 127-128). While Offred's 'ultimate fate... remains obscure' (Atwood, 1985, p. 323)-she is definitely taken from the house of the Commander, potentially to freedom - the final pages of the narrative take the form of a transcript of a speech on the preceding historical narrative, where it is revealed that the Gileadean regime has long fallen, and Offred's suffering is treated as a historical curiosity. Conversely, dystopian YA texts typically offer hope for immediate change within the life-span of the protagonists, 'prompt[ing]... readers to take responsibility and exercise their power to change the world, before it is too late' rather than offering unrelenting apocalyptic despair (Sambell, 2002, p. 164). Indeed, Clare Bradford, Kerry Mallan, John Stephens and Robyn McCallum (2008) move away from the term 'dystopian fiction', suggesting instead that these texts involve dystopian and utopian elements, depicting children and young adults as the heroes and saviours of a new world order. Given Cornell's utopian impulse, dystopian YA texts are particularly amenable to analysis in terms of the imaginary domain. 
Moreover, Lindsay Morton and Lynnette Lounsbury contend that 'dystopian YA fiction is a space where young adults can learn patterns of thinking and action to help them actively negotiate the political world... [it] highlights the effects of repression by adults, ostensibly aiming to counteract the real-world flow of power through its portrayal of active adolescents' (2015, p. 54). Themes related to sex and reproductive rights appear in these works because in dystopias, teenage protagonists are forced to make the transition from adolescence to adulthood as they integrate their newly discovered sexual desires and sense of their own identity (Gillis \& Simpson, 2015). Teenagers can identify with the characters facing challenges to their reproductive rights because ' $[\mathrm{t}$ ] hese characters must make tough choices and the consequences at that age can seem monumental' (Gillis \& Simpson, 2015, p. 76). The experiences of pregnancy and motherhood quite clearly require tough choices and monumental consequences by anyone's standards, adolescent or adult.

Teenage pregnancy, and teenage motherhood or parenthood specifically, is typically thought of as a problem in Western society, although sociologist researchers differentiate it from other problematic adolescent behaviours because 'pregnancy and parenthood are positively valued behaviours. The problem lies not with the behaviour itself, but with its timing and the implications that it has for the teen's future' (Adams, Adams-Taylor, \& Pittman, 1989, p. 225) and outcomes for the child. These include lower earnings over the parents' lifespan, increased likelihood of single parenthood, the social costs of early parenthood, higher risk of labour complications and other health issues for the mother, and children with more behavioural problems and less intellectual ability than the children of older parents as well as a lower standard of living on average (Adams et al., 1989; Aeby et al., 2016; Hoggart, 2012). As Lesley Hoggart explains, risk-based analyses of teenage pregnancy characterise teenage motherhood as a negative outcome, despite many teenage mothers viewing motherhood as improving their lives and contributing to their positive self-representation (2012, p. 537). The influential view of teenage pregnancy as a problem heightens the effect of teenage girls being the only hope for future generations in dystopian YA fiction, as it implies that adults have done such a poor job at running society that they require teenage girls to undertake a role they had previously condemned (Gillis \& Simpson, 2015). ${ }^{i i}$ 
McCafferty's novels show a clear awareness of this inconsistency and how it might give teenage girls genuine power. However, Bumped (2011) and Thumped (2012) are also careful to show that power is never given up willingly by those in authority. In this duology, threequarters of the world's population has been infected by the Human Progressive Sterility Virus and will be infertile by adulthood. One of the dual protagonists, Melody, recounts that her economic professor adoptive parents 'predicted sixteen years ago, almost before anyone else, that girls like me-prettier, smarter, healthier-would be the world's most valuable resource' (2011, p. 39). The text later includes an excerpt from her parents' publication: 'A free society cannot force girls to have children, but a free market can richly reward those who do' (2011, p. 63) and Melody explains that her parents encouraged her to 'go pro' and become a 'Surrogette' trying to win the best contract for the use of her womb. In an exaggerated, satirical style McCafferty shows how this ostensibly 'free society' manipulates teenage girls to become surrogate mothers for older infertile couples, a practice called 'pregging.' The tone of the novel is set by its opening quote, 'The United States of America once ranked above all industrialized nations in the realm of teen pregnancy... We were number one before, and we can be number one again!' (p. xii). This idea permeates Melody's world, from the Babiez R U store where she can try on a fake pregnancy belly, the Preggerz FunBump, and hear the store's jingle tell her she's 'the most important person on the planet' and was 'born to breed' (p. 1), to the pregnancy-inspired slang that she and her friends use, such as 'reproaesthetical' and 'fertilicious' for attractive, 'terminated' for exhausted and 'ectopic' for terrible. Accordingly, Melody remains indoctrinated and convinced of her power until the events of the novels challenge the accepted view that pregging for profit is an uncomplicated way to financial security, and that it can be performed without any moral conflict or physical damage.

At the beginning of the narrative, Melody unexpectedly meets her previously unknown twin sister, Harmony, who lives in a conservative, comparatively repressive Christian society called 'Goodside' that abhors the practices of the outside world such as pregging. The novels' chapters alternate between the twins' first-person perspectives, enabling readers to witness their complacent acceptance of their respective societies' value systems being 
challenged by their twin's perspective, leading to the critical reflection needed for the imaginary domain. In addition to the dramatisation of this process, the character of Zen offers thoughtful commentary that encourages this reflection, owing to his inability to fit in to his society as a male with inferior genetic material, being short. When discussing Harmony's arranged marriage Zen observes that she does have other choices, enabling Melody to recognise the parallels in her own life: 'You do... We both do' (p. 304). As identical twins raised apart, Harmony and Melody are both reflections and inversions of each other, with the events of the narrative prompting them to reject the extreme ideologies of both societies and find both common ground and independent thought as they determine their own identities.

Melody's discontent with the expectations placed on teenage girls of her society grows throughout Bumped as her friends' pregging experiences bring into question the ethics of reproducing for profit. While fearfully waiting for her friend Shoko to wake after the hysterectomy required to save her life, Melody observes a girl of eleven in labour. Outraged, she blames the girl's parents for encouraging her to give birth and self-righteously labels her 'preemie pregging' as 'very, very, down-market' (p. 266), before realising that commercial pregging had been 'down-market' in her community until Melody herself, at the urging of her parents, started the trend. Melody is overcome with emotion as she realises her own hypocrisy, as her question 'Will there be a time where there will be no such thing as too young to pregg?' (p. 266) leaves her unable to give an answer that is not arbitrary and does not bring her own actions into question. The grotesque nature of pregging is brought home to Melody as she tries to convey to an indifferent Shoko the magnitude of what she risked for a baby she will never see. Melody is reminded of her friend Malia, who refused to regard her baby in the dehumanised way implied by the preferred term of 'delivery', and consequently attempted suicide when the baby was taken away. This provides the incentive for Melody to, in Cornell's terms, enter the imaginary domain and 'imagine who [she] might be if [she]... claimed [herself] as [her] own person' $(1998$, p. 8). This process is realised for Melody over the course of Bumped's sequel, Thumped. 
Thumped reaches its culmination in Melody's televised speech in which she denounces the practice of pregging, equating it to human trafficking, and calls upon other teenage girls to have sex for their own pleasure with contraception rather than succumbing to the cultural pressure to pregg. Although she initially faces heavy criticism, especially from her perpetually absent adoptive parents, her words soon inspire other teenage girls who regret having pregged, or faked pregnancies because of the pressure, to come forward. McCafferty establishes that Melody's positive political action is the direct result of her taking moral responsibility for her choices and claiming her bodily autonomy by refusing to pregg despite her contract and reputation:

I'm still evolving into the person I'm meant to be. And though they don't know it yet, and may not come to accept it, I'm done living by [my parents'] protocols or anyone else's.

I'm the only one who will take credit for my successes.

And I'm the only one who will take the blame for my mistakes.

From now on, I live for me. (McCafferty, 2012, pp. 243-244)

However, Harmony takes longer to reach the imaginary domain. Pregnant with twins to Jondoe, the 'ReProductive Professional' hired to impregnate Melody, Harmony is overcome with guilt-over her pregnancy and for questioning elements of her faith-and resolves to be a good wife to her estranged husband Ram. Harmony struggles to accept and respond to the dramatic changes in her life while Melody's confidence in her decision is supported by additional information about the increasingly grotesque nature of pregging - the reader is told that 'every pregger gets prescribed AntiTocin [a drug that reduces the bonding hormone oxytocin] so we don't bond with our bumps' (p. 149) and recent legislation has made the wearing of a 'Maternal Obligation Moniter' mandatory for 'Professional Surrogettes' with the ironically-named 'MOM giv[ing] a warning bleep at the first sign of excess stress' (p. 30). By the conclusion of the novel, though, Harmony accepts that her birth mother is dead and will not turn up to tell Harmony who to become, encourages Ram to embrace his homosexuality, and determines the place in her life that she wants for the twins, Jondoe, 
and her religion. The Jaydens, who were contracted to adopt Melody's babies and have admitted their discomfort with the practice of pregging as well, suggest an open adoption for the twins, while Jondoe and Harmony decide to acknowledge their bond but not rush into a relationship. Both arrangements enable Harmony to engage in the work of the imaginary domain and work on her self-discovery while retaining her autonomy. The novel then ends with Harmony's dreams for her children based on the same principles, such as 'a cure to the Virus so they can choose not to share their bodies before they're ready' (p. 290), but the final lines-ostensibly also about the twins-can be read as applying to all female teenage readers:

My sister and I close our eyes. We dream of a better world. We imagine what we can-and will-do to make it possible.

For us.

And for the girls. (p. 290)

The impreciseness of the terms used in both Harmony's concluding statement and in Melody's aforementioned statement of her independence, such as 'better world' and 'my successes', gives them a resonance beyond their place in the fictional narrative. As such, McCafferty's duology 'impart[s] accessible messages that may have the potential to motivate a generation on the cusp of adulthood,' as Balaka Basu, Katherine R. Broad and Carrie Hintz say of a significant number of works of contemporary YA dystopian fiction (2013, p. 1).

Conversely, the tone of Lauren Destefano's Wither (2011), the first novel in the Chemical Garden trilogy, is considerably darker as the novel's protagonist Rhine makes a proactive choice to risk death for the slim chance of freedom. In this dystopian world, successful genetic engineering of a long-living and healthy 'first generation' has had an unexpected side-effect of their offspring succumbing to a virus at the age of twenty for females and twenty-five for males. Paradoxically, then, the younger generations are expected to act as adults before their time-particularly regarding reproduction-but are simultaneously 
treated as children by the first generation. The protagonist Rhine, as well as sister-wives Cecily and Jenna, are procured against their will as wives and producers of heirs for Linden by his first-generation father Vaughan. The three sister-wives' reactions to their captivity represent the three possible responses Destefano envisages for such a scenario: Cecily, the youngest, embraces her situation and reads as much as she can about sexuality and pregnancy despite her limited literacy; Jenna, the eldest, opts for escapism by perpetually reading and accepts a sexual relationship with Linden but will not emotionally engage with him; while Rhine does her best to act as Linden's perfect wife-although she cannot bring herself to have a sexual relationship with him-in order to be allowed enough freedom to enable her to escape. The desperate state of human fertility means that women's rights have been entirely negated, but the example of Linden suggests that some wealthy men of the younger generation, while possessing considerably more freedom than women, ${ }^{\text {iii }}$ have much less power than their elders. Rhine realises that Linden is held prisoner by his ignorance of the world's conditions, which has been encouraged by Vaughan as it allows him to use the bodies of Linden's deceased first wife and potentially murdered first child in his experimental research into a vaccine for the virus, without arousing suspicion.

Despite this revelation, Rhine does not entertain the idea of revealing the truth to Linden and recruiting him for her escape plans. This may be related to her residual feelings of hatred towards him, having initially believed that he was behind her abduction, or out of fear of Vaughan. The other likely possibility is that she envies the luxury of maintaining a naïve, childlike view of the world that Linden enjoys but she has not possessed since the death of her parents. Consequently, having seen through the deaths of her predecessor Rose and elder sister-wife Jenna that the only authorised way out of her situation is death, Rhine chooses to escape the household without Linden even realising that she had been unhappy. Instead, she leaves with her romantic interest Gabriel, the servant, whose lower social position and sensitive nature makes him little threat to her autonomy.

As Rhine's opposition to her situation is not as fully developed as a political argument as in Thumped, this narrative which evokes fairy-tales like Beauty and the Beast may be read by 
adolescents as a 'fligh[t] of fancy rather than [a projection] of a possible future' (Basu et al., 2013, p. 4). In addition, in Wither Rhine only seeks to attain freedom for herself and Gabriel, rather than plotting a revolution, which may lead readers to read the text as an adventure or romance narrative rather than a politically-motivated critique. Rhine's singularity is foregrounded from the beginning of the narrative when she is one captive potential bride amongst many held in a truck, differentiated by her feeling of alertness amongst expiring bodies and her distinctive beauty that attracts the guards' attention. Although her forced marriage to Linden would seem to be antithetical to the imaginary domain, sharing the role of wife with the other women allows Rhine the time and opportunity to meditate on her identity and desires, while her sister-wives' willingness to engage in sexual activity with Linden gives Rhine the freedom to avoid that aspect of marriage. It is significant, therefore, that while Jenna and Cecily are both prolific readers who remain comparatively passive, Rhine is the only sister-wife to narrate or author her story, and the only one to act. Thus, the novel ends with Rhine alone with her chosen partner determining their own fates, rather than as one of many potential brides subject to the will of the guards, as it began. Nevertheless, Rhine's reflections on freedom and bodily autonomy have the potential to inform and awaken readers.

Notably, McCafferty's and Destafano's protagonists Melody, Harmony and Rhine are orphans, with the only parental figures depicted (Melody's adoptive parents) remaining perpetually distant, uninformed, and largely self-obsessed. This element of their biography makes them prime candidates for rejecting the status quo; in nineteenth-century fiction for adolescent girls the orphaned girl was often the focus because of the danger she represented as she reached sexual maturity, without the appropriate socialisation and guidance of a mother figure (Sanders, 2011). The orphaned girl must reach adulthood without a parental figure that can be relied upon to protect them, forcing greater selfreliance. Moreover, in these novels the absence of a close parent-child relationship in their lives gives the orphan a greater sense of their own bodily autonomy despite the claims of their societies. ${ }^{\text {iv }}$ Thus, the inherently dangerous nature of the female adolescent orphan is 
mobilised by these authors to create heroines who refuse to accept their societies' claim to their reproductive capabilities.

Conversely, in Jane Rogers' The Testament of Jessie Lamb (2011) Jessie's quest to change a world destroyed by adults - to the extent that an unknown perpetrator chose to punish humanity by unleashing a virus that kills all pregnant women-is framed as a power struggle between father and daughter over the daughter's right to bodily autonomy. The novel begins during Jessie's imprisonment by her father, when she decides to write her 'testament' elucidating her reasons for defying her father. Jessie's narration is, therefore, the work of the imaginary domain that enables her to make a controversial but reasoned choice that she believes is her moral obligation.

As she recounts, Jessie's initial response to the universal fertility crisis was a sense of purpose. Believing that adults have shown themselves incapable of maintaining the world, Jessie and her new-found politically active teenage friends consider themselves far better equipped to direct the course of the future. However, the group she co-founds, Youth For Independence (YOFI), breaks apart as the other members fail to agree on their priorities. Consequently, when her father, a scientist at a fertility clinic, tells her about a promising project enabling unaffected babies to be born, Jessie decides that she will join in order to help save the world-even though it will come at the cost of her life. The only means of bringing forth babies that the scientists have discovered is to implant a vaccinated pre-virus embryo into the womb of an adolescent girl-the younger the womb, the better the chances-in a coma until her still unavoidable death following the birth of the baby. As the breakdown of YOFI, and the subsequent conflict between the political groups that the former members join, feeds Jessie's disillusionment with the possibility of cooperation between the people of her society, she opts to make a difference by becoming a 'Sleeping Beauty', with the hope that the next generation will be more responsible.

Jessie's choice is reasoned, justified by her moral understanding of the world, and the outcome of her process of self-discovery, but it is ultimately a passive act that requires 
abdicating bodily autonomy. Although Jessie is the only one of the discussed protagonists who agrees to have a baby, her decision could be considered equivalent to Melody's decision to forgo pregging if it were not for the fact that making that decision in her dystopian world extinguishes all other aspects of herself but the maternal function. The name given to the participants in the project is telling; as Simone de Beauvoir observes, 'the Sleeping Beauty' is the fairy-tale ideal of the woman 'who receives and submits... she is locked in a tower, a palace, a garden, a cave, she is chained to a rock, a captive, sound asleep: she waits' (1953, p. 318), the passive female complement to the active man. Jessie's father tries to convince Jessie to change her mind about becoming a 'Sleeping Beauty' by telling her that rather than heroines, they are now nothing but their anatomy: 'that's all these girls are... a belly' (Rogers, 2011, p. 182). 'Belly' here is a metonym for a womb holding a foetus, and as Cornell argues, conceptualising 'the woman as a container for the fetus reduces her "sex" to a maternal function... If we reduce women (consciously or unconsciously) to the maternal function, then we "see" them as mothers' (1995, p. 39), not as autonomous individuals. In this instance, though, the 'Sleeping Beauties' really are only 'a belly' or 'a womb' because they will not regain consciousness nor live past the birth of their baby. Although the choice to join them is Jessie's own, made in defiance of her parents' wishes, she willingly forgoes consciousness and then life, becoming nothing but the maternal function.

Unlike the protagonists of McCafferty's and Destafano's texts, Jessie ultimately accepts her circumscribed role and naively refuses to see that her triumph over her father is not a symbolic victory over the patriarch, but submission to the flawed society of adults that she continues to bemoans. This blindness is foreshadowed by her inability to decide whether she agrees with the arguments made by the radical feminist group, Feminist Link Against Men (FLAME), or the rebuttals she imagines her father making. However, the text presents Jessie's decision as a noble one. Her description of her story as a 'testament', combined with the similarity between the name Jessie Lamb and Jesus the Lamb of God, cast her as a Jesuslike figure and thus gives the concept of sacrifice a positive association. 
Accordingly, Jessie's use of the imaginary domain enables her to take action that is powerful in the sense that that it proclaims her bodily and moral autonomy, but it remains problematic from a feminist point of view. Moreover, her transference of responsibility to future generations has positive connotations when considered through the lens of the symbolism of Jesus, and the opposite when analysed in terms of the imaginary domain. Jessie's acceptance that the world will not be saved while she exists undermines her process of identity formation, as it implies that she is only worthy as a carrier of life, not a life in her own right.

Another significant difference between The Testament of Jessie Lamb and the other texts is that the process by which Jessie will bear a child is entirely scientific, requiring no physical contact with another person. As the narrative leading up to Jessie's decision tracks her burgeoning sexuality - she is kissed against her will by lain, an elder member of YOFI, which adds to her decision to leave the group, and experiences sex with her love interest Bazthere is a clear division between desire and reproduction. In Wither, this division is murkier. The sister-wives are expected to have a sexual relationship with Linden in order to produce children, and all three approach this differently: Cecily, who researches pregnancy and sex, embraces her role whole-heartedly; Jenna, having worked as a prostitute in the past, pretends to offer her husband a passionate sexual relationship but actually has no desire for him; while Rhine develops an illicit romantic bond with Gabriel and refuses to betray her true desires through a sexual relationship with Linden, even though she realises this might destroy her plans to become his favourite, win freedom and escape. Conversely, in Bumped and Thumped the cultural obsession with pregging results in an extreme level of sexualisation of teenagers. However, because teenagers are expected to pregg for adults and the adults themselves tend to be infertile, ${ }^{\text {vi }}$ condoms and other forms of contraception have been made illegal in the United States. Reproduction is encouraged for teenagers, therefore, but not sex as an expression of desire-even having sex while pregnant is rumoured to be dangerous and may void one's contract. The sexualisation of teenagers is therefore another means by which the culture, developed by the adults, manipulates teenagers into choosing to pregg. The values informing pregging are also reminiscent of the 
tendency for sex education to focus on the danger of sex and its reproductive function rather than the potential for pleasure, especially when it is being discussed with girls (Lamb, Lustig, \& Graling, 2013). Although the understanding of the 'danger' of sex is modified in the novels to suit the priorities of adults, the general issue is addressed in Melody's televised speech when she argues that '[w]e should be able to bond emotionally and physically-not either/or' (McCafferty, 2011, p. 265). Thus, 'the fight for a better world is itself a fight for love, as dystopian forces keep teenagers from choosing their own mates' in novels such as Bumped and Thumped as well as Wither, in which the illegitimacy of Rhine's marriage to Linden is contrasted with her authentic burgeoning relationship with Gabriel (Basu et al., 2013, p. 8). On the issue of the right to have sex for pleasure and as an expression of desire, then, although the three texts address the issue from different angles, they all contend that teenage girls should have the freedom to choose to have sex for pleasure and to express their desire, as well as choose not to have sex if it will not bring them pleasure and express their desire.

As previous studies of YA dystopian novels have shown, they are shaped by their intended audience, ending on a more hopeful note than dystopian novels written for adults. Those that engage with the issue of reproductive rights, moreover, ask readers to consider themselves as sexual subjects and take responsibility for that sexual subject, even if it means rejecting external forces who seek to dictate what their bodies and desires mean. While Bumped and Thumped have a strong political edge that is maintained throughout the duology and makes a clear call for action, Wither's focus on the protagonist at the expense of the outside world and The Testament of Jessie Lamb's somewhat defeatist conclusion means that they are less likely to have a strong effect on readers unless the readers are already politically aware. While Melody and Harmony achieve recognisably feminist identities through their experiences of the imaginary domain, the processes of identity formation that Rhine and Jessie undergo do not inspire them to make changes in their societies. Nevertheless, by embedding these issues into their dystopian worlds, McCafferty, Destefano and Rogers prompt readers to consider how their sexuality and reproductive capabilities inform their identities and place in the world-as Cornell writes, '[t]he question 
of who we are as sexed beings takes us into the deepest recesses of what lies buried under civilization' (1998, p. 24).

\section{Notes}

i. Although The Handmaid's Tale will be discussed briefly throughout this paper, the paper's scope prevents any extended analysis of the novel. For further discussion of its representation of and reflection on reproductive politics, see Craig (2013), Latimer (2009) and Myrsiades (1999).

ii. It should be noted, though, that the adolescent mothers of the discussed texts are not expected to raise the children themselves, even when they want to, such as Cecily in Wither and Malia in Bumped.

iii. As in The Handmaid's Tale, wealthy and upper-class men in Wither have considerably more status than lower-class men. In fact, the superfluous male servant Adair is 'sold off in an auction' (Destefano, 2011, p. 337), showing that few in the world of the novel can claim autonomy.

iv. Harmony's sense of her own bodily autonomy is initially less than the other two characters mentioned because of her religious faith and belief in her body as a possession of God-she is raised to 'live in JOY: Jesus first, Others next, Yourself last' (McCafferty, 2011, p. 12)-but her experiences over the course of the novels inspire greater awareness of her bodily autonomy.

v. Melody claims that $85 \%$ of the world rather than $100 \%$ are affected by the virus, but there is no mention of any adults procreating in the novels.

\section{References}

Adams, Gina; Adams-Taylor, Sharon \& Pittman, Karen (1989). Adolescent pregnancy and parenthood: A review of the problem, solutions, and resources. Family Relations, 38(2), 223229.

Aeby, Victor G.; Xu, Lei; Carpenter-Aeby, Tracy; Lu, Wenhua; Barnes, Ericka Samone; Rivers, Desirae, \& Turner, LaTerriar (2016). Exploring Planned Parenthood, Teen Pregnancy, and Policy-A Systematic Literature Review. US-China Education Review, 6(5), 293-301.

Anderson, Joel, \& Claassen, Rutger (2012). Sailing alone: Teenage autonomy and regimes of childhood. Law and Philosophy, 31(5), 495-522.

Atwood, Margaret (1985). The Handmaid's Tale. London: Vintage Books.

Basu, Balaka; Broad, Katherine R. \& Hintz, Carrie (2013). Introduction. In C. Hintz, B. Basu \&

K. R. Broad (Eds.), Contemporary Dystopian Fiction for Young Adults: Brave New Teenagers

(pp. 1-15). New York: Routledge.

Beauvoir, Simone de (1953). The Second Sex (H. M. Parshley, Trans.). London: Vintage Books. Bradford, Clare; Mallan, Kerry; Stephens, John \& McCallum, Robyn (2008). New World Orders in Contemporary Children's Literature: Utopian Transformations. Houndmills, Basingstoke, Hampshire: Palgrave Macmillan.

Browner, Carole H. (2015). Reproduction: From Rights to Justice? In L. Disch \& M.

Hawkesworth (Eds.), The Oxford Handbook of Feminist Theory (pp. 1-34). Oxford Handbooks

Online: Oxford. doi: 10.1093/oxfordhb/9780199328581.013.40 
Bullen, Elizabeth, \& Parsons, Elizabeth (2007). Dystopian visions of global capitalism: Philip Reeve's Mortal Engines and MT Anderson's Feed. Children's Literature in Education, 38(2), 127-139.

Cornell, Drucilla (1995). Bodily integrity and the right to abortion. In A. Sarat \& T. R. Kearns (Eds.), Identities, Politics and Rights (pp. 21-84). Ann Arbor: The University of Michigan Press. Cornell, Drucilla (1998). At the Heart of Freedom: Feminism, Sex, and Equality. Princeton: Princeton University Press.

Craig, Layne Parish (2013). Birth Control's Afterlives When Sex Changed: Birth Control Politics and Literature Between the World Wars. New Brunswick, NJ: Rutgers University Press.

Destefano, Lauren (2011). Wither. London: Harper Voyager.

Fischel, Joseph J. (2016). Sex and Harm in the Age of Consent: University of Minnesota Press. Gillis, Bryan \& Simpson, Joanna (2015). Sexual Content in Young Adult Literature: Reading Between the Sheets (Vol. 48). Lanham, Maryland: Rowman \& Littlefield.

Hoggart, Lesley (2012). 'I'm pregnant... what am I going to do?'An examination of value judgements and moral frameworks in teenage pregnancy decision making. Health, risk \& society, 14(6), 533-549.

Kokkola, Lydia (2013). Fictions of Adolescent Carnality: Sexy Sinners and Delinquent Deviants. Amsterdam and Philadelphia: John Benjamins Publishing.

Lamb, Sharon; Lustig, Kara \& Graling, Kelly (2013). The use and misuse of pleasure in sex education curricula. Sex Education, 13(3), 305-318.

Latimer, Heather (2009). Popular culture and reproductive politics: Juno, Knocked Up and the enduring legacy of The Handmaid's Tale. Feminist Theory, 10(2), 211-226.

Lovell, Kera (2016). Girls are equal too: Education, body politics, and the making of teenage Feminism. Gender Issues, 33(2), 71-95.

McCafferty, Megan (2011). Bumped. London: Corgi Books.

McCafferty, Megan (2012). Thumped. London: Corgi Books.

Morton, Lindsay, \& Lounsbury, Lynnette (2015). Inertia to action: From narrative empathy to political agency in young adult fiction. Papers: Explorations into Children's Literature, 23(2), 53.

Myrsiades, Linda (1999). Law, Medicine, and the Sex Slave in Margaret Atwood's The Handmaid's Tale. Un-Disciplining Literature: Literature, Law and Culture, 219-245.

Newhall, Lynne (2011). Women in Law - Bodily Autonomy - 'The Entombed Womb' within the realm of 'Body Politics' it could be argued that the law fails to support and protect women's bodily autonomy. Bracton Law Journal, 43, 59-71.

Penguin Books (2018). Margaret Atwood announces sequel to The Handmaid's Tale: The Testaments. Retrieved 13 December 2018, from

www.penguin.co.uk/articles/2018/nov/margaret-atwood-announces-sequel-handmaidstale-the-testaments/

Pollitt, Katha (2015). Pro: Reclaiming Abortion Rights. New York: Picador.

Rogers, Jane (2011). The Testament of Jessie Lamb. Edinburgh and London: Canongate. Sambell, Kay (2002). Presenting the case for social change: The creative dilemma of dystopian writing for children. In C. Hintz \& E. Ostry (Eds.), Utopian and Dystopian Writing for Children and Young Adults (pp. 163-178). New York and London: Routledge. 
Sanders, Joe Sutliff (2011). Disciplining Girls: Understanding the Origins of the Classic Orphan Girl Story. Baltimore, Maryland: The Johns Hopkins University Press.

Solinger, Rickie (2007). Pregnancy and Power: A Short History of Reproductive Politics in America. New York and London: New York University Press.

Teen Bestsellers. (2017). Retrieved 26 June 2017, from

www.barnesandnoble.com/b/books/teens/_/N-1fZ29Z8q8Z19r4

Tolman, Deborah L.; Striepe, Meg I. \& Harmon, Tricia (2003). Gender matters: Constructing a model of adolescent sexual health. Journal of sex research, 40(1), 4-12.

Trites, Roberta S. (1998). Disturbing the Universe: Power and Repression in Adolescent

Literature. lowa City: University of lowa Press.

Watson, Emma (2017). Our Shared Shelf. Retrieved 26 June 2017, from

www.goodreads.com/group/show/179584-our-shared-shelf

\section{Biographical Note}

Ilona Urquhart (PhD, Deakin University) currently teaches in the discipline of children's literature at Deakin University and assists Deakin University's Teenagers Reading and Digital Practices Research Group. She has a strong interest in the provision of books and other resources for young adults in libraries. Her research interests include feminism in YA fiction, Gothic YA fiction and domestic noir. 